\title{
Utility of Fishes as Bio-indicators for Tracing Metal Pollution in the Cochin Backwaters, Kerala, India
}

\author{
M. Jyothirmaye, A. Biju* and G. Rejomon ${ }^{1}$ \\ Zoology Research Centre (University of Kerala), St. Stephen's College, Pathanapuram-689 695, India \\ ${ }^{1}$ P.G Department of Chemistry, Bishop Abraham Memorial College, Thuruthicad-689 597, India \\ *E-mail: bijuanio75@gmail.com
}

\begin{abstract}
Trace metal (Fe, Ni, $\mathrm{Zn}, \mathrm{Cu}, \mathrm{Pb}, \mathrm{Cd}$ and $\mathrm{Cr}$ ) concentrations in water and tissues (flesh, gills and liver) of two fishes, Etroplus suratensis and Arius arius from the Cochin backwaters were investigated during February 2017 to January 2018. Trace metals were analysed using an Atomic Absorption Spectrophotometer (AAS). The omnivorous species, E. suratensis showed a higher concentration of trace metals in tissues than the carnivorous species, $A$. arius. Bioaccumulation of metals in fish tissues showed higher levels in the liver, which was followed by gill and flesh maybe due to the different physiological roles of these organs in fish metabolism. Bioaccumulation factors (BAF) of metals calculated for the species, E. suratensis follows an order $\mathrm{Fe}>\mathrm{Zn}>\mathrm{Ni}>\mathrm{Cu}>\mathrm{Cr}>\mathrm{Pb}>\mathrm{Cd}$ whereas that for the species, $A$. arius follows an another order $\mathrm{Fe}>\mathrm{Zn}>\mathrm{Cr}>\mathrm{Cu}>\mathrm{Ni}>\mathrm{Pb}>\mathrm{Cd}$. Comparatively higher BAF values in organs of fishes indicate the increased concentration of the soluble metal in the medium in which the fishes inhabit. Metal selectivity index (MSI) and tissue selectivity index (TSI) are better tool for explaining bioaccumulation of trace metals in fishes. The results of the present study suggest the potential use of fishes, $E$. suratensis and $A$. arius as bioindicators for tracing metal pollution in the estuarine environment of Cochin.
\end{abstract}

Keywords: Trace metal, Bio-indicators, Fishes, Metal selectivity index, Tissue selectivity index, Cochin backwaters

Monitoring and analysis of trace metals in the environmental compartments of aquatic systems are necessary for pollution assessment and control (Elzwayie et al 2017). For a meaningful assessment of environmental impacts of metal pollution, measurement of metal concentrations in selected aquatic species of the resident biota in an ecosystem is necessary. Fishes are considered one of the most significant bio-indicators in aquatic systems to estimate metal pollution (Authman 2008, Al-Kahtani 2009). As fishes are located at the top of the aquatic food chains, the accumulated metals in their various tissues may pass to human beings through consumption of fish which may cause chronic or acute diseases (Al-Yousuf et al 2000). Hence, it is necessary to estimate the bioaccumulation of trace metals in fishes for monitoring water pollution and assessing potential risks associated with consuming the contaminated fish concerning human health (Ural et al 2012). The bioaccumulation of toxic metals in fishes has been a matter of public health concern since fish forms a part of the diet for a majority of the human population. The bioaccumulation of toxic contaminants in fish is caused by its uptake from ambient medium and through its diet (George et al 2012). Many factors depend on the retention of trace metals in the fish's body, such as the speciation of the metal concerned, the physiological mechanism for regulation, homeostasis and detoxification of the metal. Depending on the structure and function, the degree of accumulation of trace metals in fish tissues may vary. Generally, metabolically active tissues like gills, liver and kidneys have a higher accumulation of trace metals than the other tissues like muscles and skin (Hazrat et al 2019). The mechanism by which trace metal accumulates in tissues of different fish species appears to be a complex biochemical phenomenon that was not fully explored (George et al 2021). The accumulation of trace metals in fish tissues partly depends on metal concentrations in water and the duration of exposure. Moreover, environmental factors such as water temperature, oxygen concentration, $\mathrm{pH}$, hardness, salinity, alkalinity and dissolved organic carbon play a significant role in the metal accumulation and toxicity to fish. The present study aims to evaluate and quantify the bioaccumulation of trace metals (Fe, Ni, Zn, Cu, Pb, Cd and $\mathrm{Cr}$ ) in tissues (flesh, liver and gills) of two species of fishes, Etroplus suratensis and Arius arius collected from the Cochin Back waters.

\section{MATERIAL AND METHODS}

Study area: The Cochin backwaters, extending between (Lat. $9^{\circ} 30^{\prime}-10^{\circ} 10^{\prime} \mathrm{N}$ and Long. $76^{\circ} 15^{\prime}-76^{\circ} 25^{\prime} \mathrm{E}$ ) are located at the northern part of the Vembanad Lake which forms a complex network of the shallow brackish water body. This backwater system is subjected to inputs of various organic as well as inorganic contaminants from its neighbouring 
hinterlands. The estuary was polluted by trace metals loaded from industrial, agricultural and municipal sources (Jayasooryan 2015, George et al 2016, Lallu 2017). The main source of metal pollution to the central part of the estuary seems to be due to the processing of metalcontaining minerals (ores) at the FACT plant, paints and pigments that are used at the shipyard and ports (George et al 2016). The southern part of the estuary is subjected to metal pollution due to land runoff from Kuttanad agricultural fields that make use of excessive fertilizers and pesticides. Three seasonal conditions viz. pre-monsoon (PrM), monsoon (M) and post-monsoon (PoM) were prevailing in the study region. For this study five stations were selected from central to the southern part of Cochin backwaters based on the geographic features, anthropogenic activities and the inflow of pollutants from the different sources (Fig. 1).

Sample collection: A bimonthly water and fish samples were collected from Cochin backwaters during February 2017 to January 2018. This work was conducted in Zoology Research Centre, St. Stephens College, Pathanapuram, India. Water samples for the analysis of dissolved trace metals were collected using a pre-sterilized plastic bucket and were stored in plastic bottles that are pre-sterilized with $1 \mathrm{~N} \mathrm{HCl}$. Water samples taken in plastic bottles were fixed with $1 \mathrm{ml}$ of $70 \% \mathrm{HNO}_{3}$ and were preserved at about $4{ }^{\circ} \mathrm{C}$ in a

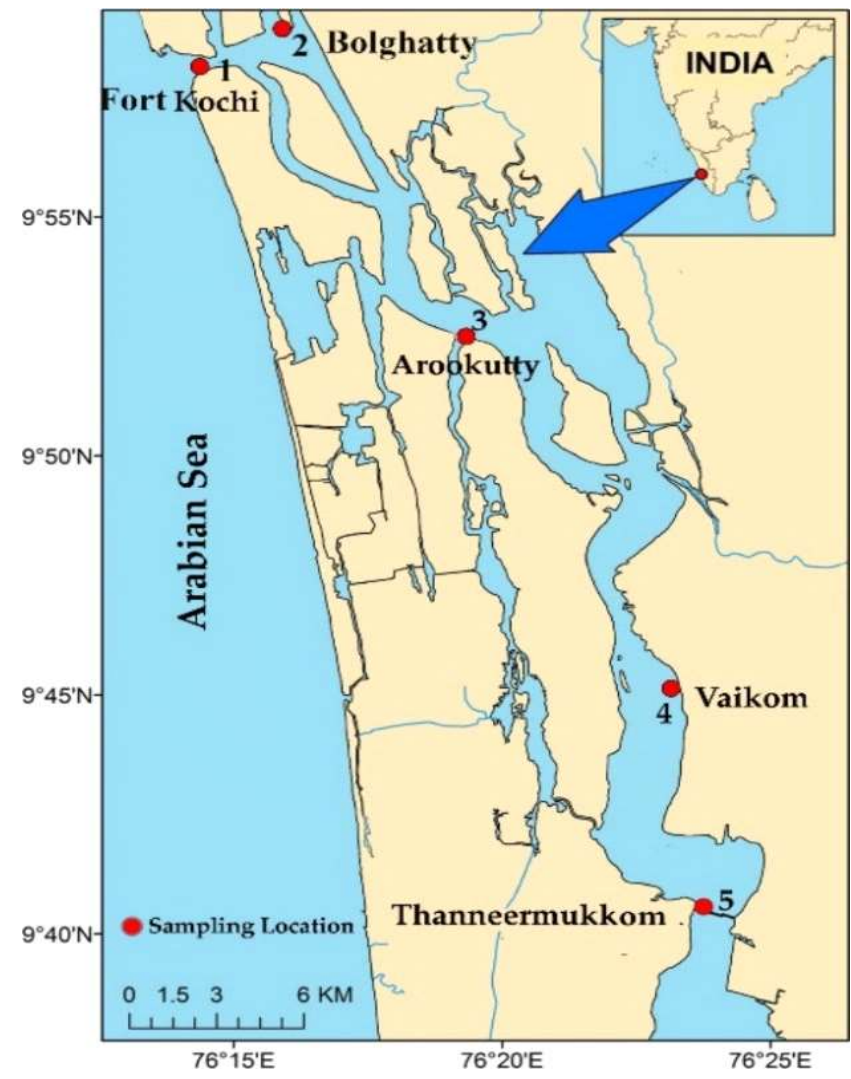

Fig. 1. Sampling locations refrigerator till analysis in a Graphite Furnace AAS. Two species of fishes, E. suratensis (locally called Karimeen) and Arius arius (Koori) in the Cochin backwaters were collected directly from the local fishermen. The selected species are economically important and abundant in the study area. Eighty samples of fishes (40 samples of $E$. suratensis and 40 samples of $A$. arius) were collected from the sampling area. Immediately after the collection, fish samples were washed thoroughly with distilled water to remove mud or other fouling substances and were put in a clean polythene bag. They were preserved in iceboxes packed with ice in order to maintain the freshness and were transported to the laboratory. In the laboratory, fish samples were weighed and recorded for their total length. The flesh, liver and gills of the fish samples were dissected and washed thoroughly with distilled water. The organs were dried in an oven at $65^{\circ} \mathrm{C}$. The dried samples were powdered using mortar and pestle and were stored in a vacuum desiccator.

Trace metal analysis: The aliquots of about $300 \mathrm{mg}$ were digested for $3 \mathrm{~h}$ at $80^{\circ} \mathrm{C}$ with $3 \mathrm{ml}$ conc. $\mathrm{HNO}_{3}(65 \%$ Merck, Suprapure) in Teflon beakers. Additional nitric acid was added if the samples were charred and $1 \mathrm{ml}$ of conc. $\mathrm{HClO}_{4}$ (Merck Suprapure) was added to make the solution clear and evaporated to near dryness. The digests were cooled and diluted to $25 \mathrm{ml}$ with deionised water and were kept in plastic vials. Trace metals were analysed using an Atomic Absorption Spectrophotometer (AAS) Perkin Elmer India Pvt. Ltd. (Model: Pinaacle 900H). All metal concentrations in tissues of fish species were reported in ppm, dry weight.

Bioaccumulation factors (BAF) or Concentration factors were calculated for each metal as the ratio between the metal concentrations in the organism's body to its concentration in the ambient medium. Bioaccumulation factors (BAF) were used in assessment models as they provide pollution scaleindependent parameter (Karlsson et al 2002).

$$
\mathrm{BAF}=\frac{\text { The metal concentration in organism's body }}{\text { Metal concentration in the ambient medium (Water) }}
$$

Metal Selectivity Index (MSI) was calculated as the percentage of absolute concentration of a particular metal in tissue to the total concentration of all metals in that tissue (Nair et al 2006). MSI gives the affinity of a particular metal to a particular organ or tissue and is used as a reliable index for risk assessment of that particular metal.

$$
\mathrm{MSI}=\frac{\text { Absolute concentration of a metal in a tissue }}{\text { Total concentration of all metals in that tissue }} \times 100
$$

Tissue selectivity index (TSI) is the percentage of the ratio between the absolute concentration of a metal in tissue and the total concentration of that metal in all the tissues (Nair et al 2006). 
$\mathrm{TSI}=\frac{\text { Absolute concentration of a metal in a tissue }}{\text { Total concentration of all metals in that tissue }} \times 100$

\section{RESULTS AND DISCUSSION}

Trace metal concentrations in water: The concentrations of $\mathrm{Fe}, \mathrm{Ni}, \mathrm{Zn}, \mathrm{Cu}, \mathrm{Pb}, \mathrm{Cd}$ and $\mathrm{Cr}$ in water ranged from 0.051 to $0.284 \mathrm{mg} \mathrm{L}^{-1}, 0.008$ to $0.112 \mathrm{mg} \mathrm{L}^{-1}, 0.012$ to $0.341 \mathrm{mg} \mathrm{L}^{-1}$, 0.009 to $0.126 \mathrm{mg} \mathrm{L}^{-1}, 0.013$ to $0.199 \mathrm{mg} \mathrm{L}^{-1}, 0.002$ to 0.095 $\mathrm{mg} \mathrm{L}^{-1}$ and 0.018 to $0.124 \mathrm{mg} \mathrm{L}^{-1}$ respectively. The mean concentration of trace metals in water $\left(\mathrm{mg} \mathrm{L}^{-1}\right)$ follows a decreasing order: $\mathrm{Fe}>\mathrm{Zn}>\mathrm{Pb}>\mathrm{Cr}>\mathrm{Cu}>\mathrm{Ni}>\mathrm{Cd}$ (Table 1). The increased concentration of trace metals in the water might be due to the large quantities of solid wastes mixed with the wastes of factories, market and industrial wastes that either discharge directly into the water bodies or dumped in open land fill which are directed to the water bodies through the rainwater runoff (Elamin et al 2021). In Cochin backwaters, the dissolved phase is the most sensitive compartment to every change in hydrographical conditions of the water column due to its large surface area and shallow depth (1.5-6 m) (Anu et al 2014).

Hence, seasonally the concentration of dissolved metals in the water column may vary due to variations in the magnitude of freshwater discharges from rivers, discharge of industrial effluents and domestic sewage, and leakage of pesticide and fertilizer residues from agricultural fields. Thus,

Table 1. Trace metal concentration in water $\left(\mathrm{mg} \mathrm{L}^{-1}\right)$ from the Cochin backwaters

\begin{tabular}{lc}
\hline Trace metals & Mean \pm SD \\
\hline $\mathrm{Fe}$ & $0.284 \pm 0.267$ \\
$\mathrm{Ni}$ & $0.049 \pm 0.025$ \\
$\mathrm{Zn}$ & $0.093 \pm 0.091$ \\
$\mathrm{Cu}$ & $0.064 \pm 0.033$ \\
$\mathrm{~Pb}$ & $0.079 \pm 0.044$ \\
$\mathrm{Cd}$ & $0.038 \pm 0.025$ \\
$\mathrm{Cr}$ & $0.066 \pm 0.029$ \\
\hline
\end{tabular}

the increased concentrations of metals in the water column due to anthropogenic activities act as a significant source to the increased metal levels in fishes of the Cochin backwaters (Hannibal et al 2006, George et al 2012).

Trace metal concentrations in fishes: The trace metal concentrations (in ppm, dry weight) in flesh, gill and liver tissues of fishes, $E$. suratensis and $A$. arius were presented in (Table 2). Marked variations were found in the concentrations of trace metals in flesh, gill and liver of $E$. suratensis and $A$. arius that collected from the Cochin backwaters. In general, the studied fish species showed a higher concentration of metals in the liver with few exceptions and the lowest concentrations of metals were found in the flesh.

The average concentrations of $\mathrm{Fe}, \mathrm{Ni}, \mathrm{Zn}, \mathrm{Cu}, \mathrm{Pb}, \mathrm{Cd}$ and $\mathrm{Cr}$ in $\mathrm{E}$. suratensis were $290.39,23.52,84.85,11.24$, $8.33,4.00$ and 34.76 respectively in flesh, 820.89, 40.67, $252.94,51.17,28.29,7.33$ and 50.50 respectively in liver, $712.45,45.75,210.05,24.50,17.04,7.86$ and 46.10 respectively in gills (Table 2 ). The average concentrations of $\mathrm{Fe}, \mathrm{Ni}, \mathrm{Zn}, \mathrm{Cu}, \mathrm{Pb}, \mathrm{Cd}$ and $\mathrm{Cr}$ in flesh of $A$. arius were 266.01, $21.20,62.98,9.37,8.80,3.51$ and 19.02 respectively in flesh, $719.95,31.00,196.89 .45 .24,15.69,6.76$ and 47.45 respectively in liver and 610.06, 29.76, 166.03, 17.86, 19.30, 6.86 and 40.35 respectively in gills (Table 2). The average concentration of trace metals accumulated in $E$. suratensis follows an order: $\mathrm{Fe}>\mathrm{Zn}>\mathrm{Cr}>\mathrm{Ni}>\mathrm{Cu}>\mathrm{Pb}>\mathrm{Cd}$ for flesh, $\mathrm{Fe}$ $>\mathrm{Zn}>\mathrm{Cu}>\mathrm{Cr}>\mathrm{Ni}>\mathrm{Pb}>\mathrm{Cd}$ for gill, and $\mathrm{Fe}>\mathrm{Zn}>\mathrm{Cr}>\mathrm{Ni}>$ $\mathrm{Cu}>\mathrm{Pb}>\mathrm{Cd}$ for liver, respectively. In $A$. arius the trace metals accumulated follows an order: $\mathrm{Fe}>\mathrm{Zn}>\mathrm{Ni}>\mathrm{Cr}>\mathrm{Cu}$ $>\mathrm{Pb}>\mathrm{Cd}$ for flesh, $\mathrm{Fe}>\mathrm{Zn}>\mathrm{Cr}>\mathrm{Ni}>\mathrm{Cu}>\mathrm{Pb}>\mathrm{Cd}$ for gill and $\mathrm{Fe}>\mathrm{Zn}>\mathrm{Cr}>\mathrm{Cu}>\mathrm{Ni}>\mathrm{Pb}>\mathrm{Cd}$ for liver, respectively (Table 2). Trace metal bioaccumulation in fish depends on the trophic level, size, food and feeding habits (Sankar et al 2006, George et al 2012, 2021). Dietary preferences, foraging behaviours and food web structure also influence metal bioaccumulation in fishes (Geldiay and Balik 2000). The concentration of trace metals detected in fish organs of $E$. suratensis and $A$. arius indicates different bioaccumulation

Table 2. Trace metal concentration in fishes (ppm) of the Cochin backwaters

\begin{tabular}{lcccccccc}
\hline Trace metals & \multicolumn{3}{c}{ E. suratensis } & & \multicolumn{3}{c}{ A. arius } \\
\cline { 2 - 4 } & Flesh & Liver & Gills & & Flesh & & Liver & Gills \\
\hline $\mathrm{Fe}$ & $290.39 \pm 103.57$ & $820.89 \pm 345.66$ & $712.45 \pm 249.58$ & & $266.01 \pm 118.97$ & $719.95 \pm 188.80$ & $610.06 \pm 200.06$ \\
$\mathrm{Ni}$ & $23.52 \pm 9.15$ & $40.67 \pm 16.95$ & $45.75 \pm 14.12$ & & $21.20 \pm 7.60$ & $31.00 \pm 11.25$ & $29.76 \pm 8.45$ \\
$\mathrm{Zn}$ & $84.85 \pm 43.97$ & $252.94 \pm 106.62$ & $210.05 \pm 91.85$ & & $62.98 \pm 23.22$ & & $196.89 \pm 68.42$ & $166.03 \pm 51.62$ \\
$\mathrm{Cu}$ & $11.24 \pm 7.25$ & $51.17 \pm 25.53$ & $24.50 \pm 15.31$ & & $9.37 \pm 5.87$ & & $45.24 \pm 21.20$ & $17.86 \pm 9.84$ \\
$\mathrm{~Pb}$ & $8.33 \pm 5.00$ & $28.29 \pm 24.28$ & $17.04 \pm 13.13$ & & $9.67 \pm 4.35$ & & $15.69 \pm 8.18$ & $19.30 \pm 9.44$ \\
$\mathrm{Cd}$ & $4.00 \pm 1.61$ & $7.33 \pm 4.34$ & $7.86 \pm 4.69$ & & $3.51 \pm 1.52$ & & $6.69 \pm 3.83$ & $6.86 \pm 3.64$ \\
$\mathrm{Cr}$ & $34.76 \pm 20.08$ & $50.50 \pm 20.84$ & $46.10 \pm 22.33$ & & $19.02 \pm 9.32$ & & $47.45 \pm 18.55$ & $40.18 \pm 20.81$ \\
\hline
\end{tabular}


potentials (Mahesh et al 2012). The interspecies variability in metal accumulation can be explained by species-specific differences in bioaccumulation dynamics.

In general, the concentration of trace metals was higher in the omnivorous species, E. suratensis when compared to the carnivorous species, $A$. arius. The concentration of Fe, $\mathrm{Zn}, \mathrm{Cu}$ and $\mathrm{Cd}$ in organs of $E$. suratensis follow an order liver $>$ gill > flesh while the $\mathrm{Ni}, \mathrm{Pb}$ and $\mathrm{Cr}$ follow another order gills $>$ liver $>$ flesh. Similarly in A. arius, the $\mathrm{Fe}, \mathrm{Zn}, \mathrm{Cu} \mathrm{Pb}, \mathrm{Cd}$ and $\mathrm{Cr}$ concentration in the organs follow an order liver $>$ gill $>$ flesh, while, the Ni follow another order gills > liver $>$ flesh. The omnivorous fish species, E. suratensis, showed higher concentrations of metals when compared to the carnivorous fish species, $A$. arius. This may be due to the feeding of $E$. suratensis, in both benthic and pelagic zones of the backwaters. E. suratensis, is a bentho-pelagic species and hence can feed on both benthic and pelagic food chains which enhances its trace metal accumulation behaviour when compared to the benthic species, $A$. arius (Yousafzai et al 2012, Siraj et al 2014, Obasohan 2008).

Bioaccumulation factor (BAF): The degree to which bioaccumulation occurs can be expressed as bioaccumulation factor and is evaluated in relation to the concentration of the soluble metal in the medium (water) in which the fishes inhabit. The concentration factor of the elements in the species $E$. suratensis and $A$. arius are in the order: $\mathrm{Fe}>\mathrm{Zn}>\mathrm{Ni}>\mathrm{Cu}>\mathrm{Cr}>\mathrm{Pb}>\mathrm{Cd}$ and $\mathrm{Fe}>\mathrm{Zn}>\mathrm{Cr}>\mathrm{Cu}$ $>\mathrm{Ni}>\mathrm{Pb}>\mathrm{Cd}$ respectively. Of the fishes examined, $E$. suratensis showed a higher range of bioaccumulation factors for all the metals in the liver (Table 3). The bioaccumulation factor of elements in liver of the species $E$. suratensis and $A$. arius follows the order: $\mathrm{Fe}>\mathrm{Zn}>\mathrm{Ni}>\mathrm{Cu}>\mathrm{Cr}>\mathrm{Pb}>\mathrm{Cd}$ and $\mathrm{Fe}>\mathrm{Zn}>\mathrm{Cr}>\mathrm{Cu}>\mathrm{Ni}>\mathrm{Pb}>\mathrm{Cd}$, respectively. In general, the higher values of BAF found in plankton followed by zoobenthos, predator fish and herbivorous fishes which is mainly depending up on the organism placed in the food chain, their feeding behaviour, hydrology and age of the organism (Culioli et al 2009, Tao et al 2012, Pantelica et al
2012). In the present study comparatively higher BAF values were observed in organs of studied fishes (Table 3), indicate the increased concentration of the soluble metal in the medium (water) in which the fishes inhabit. Many other studies reported the highest BAF in the fish organs and the tissues as $\mathrm{Fe}$ and $\mathrm{Zn}$ followed by $\mathrm{Cu}, \mathrm{Pb} \mathrm{Cd}$ and $\mathrm{As}$ (Uluturhan and Kucuksezgin 2007, Ayotunde et al 2012, Nwani et al 2010, Farombi et al 2007). Most metals showed a decreasing BAF in higher chains of food web, from phytoplankton to zooplankton, then fish (Tiphaine et al 2019). The BAFs of many elements in a given type of organism are much lower in marine waters compared to the freshwater environments, whereas the opposite is true for some elements.

Metal selectivity index (MSI) and Tissue selectivity index (TSI): Metal selectivity index (MSI) measures the affinity of a species to accumulate a particular metal in that tissue or organ of the body and is calculated for all the metals. MSI values (\%) for different organs of fishes (Table 4). In $E$. suratensis, $\mathrm{MSI}$ values follows an order: $\mathrm{Fe}>\mathrm{Zn}>\mathrm{Cr}>\mathrm{Ni}>$ $\mathrm{Cu}>\mathrm{Pb}>\mathrm{Cd}$ in flesh and gills but in liver it follows another order: $\mathrm{Fe}>\mathrm{Zn}>\mathrm{Cr}>\mathrm{Ni}>\mathrm{Cu}>\mathrm{Pb}>\mathrm{Cd}$. In A. arius, MSI values were in the order: $\mathrm{Fe}>\mathrm{Zn}>\mathrm{Ni}>\mathrm{Cr}>\mathrm{Cu}>\mathrm{Pb}>\mathrm{Cd}$ in flesh, $\mathrm{Fe}>\mathrm{Zn}>\mathrm{Cr}>\mathrm{Cu}>\mathrm{Ni}>\mathrm{Pb}>\mathrm{Cd}$ in liver and $\mathrm{Fe}>\mathrm{Zn}>$ $\mathrm{Cr}>\mathrm{Ni}>\mathrm{Cu}>\mathrm{Pb}>\mathrm{Cd}$ in gills. In both fishes, $\mathrm{Fe}$ and $\mathrm{Cd}$ showed the highest and lowest MSI values, respectively. The relative tissue occupying capacity of metal in a particular tissue is known as Tissue Selectivity Index (TSI). The tissue selectivity of trace metals in fishes is determined by the bioavailability of metals in the environmental matrix, feeding behaviour and metabolic activities. The TSI values (\%) for different organs of fishes are given in (Table 5). In $E$. suratensis, the TSI values for the metals $\mathrm{Fe}, \mathrm{Zn}, \mathrm{Cu}, \mathrm{Pb}$ and Cr follow an order: liver $>$ gill $>$ flesh whereas for the metals $\mathrm{Ni}$ and $\mathrm{Cd}$ it follows another order: gills $>$ liver $>$ flesh. $\ln A$. arius the TSI values for the metals $\mathrm{Fe}, \mathrm{Ni}, \mathrm{Zn}, \mathrm{Cu}$ and $\mathrm{Cr}$ follow an order liver > gill > flesh whereas for the metals $\mathrm{Pb}$ and $\mathrm{Cd}$ it follows another order: gills $>$ liver $>$ flesh.

Table 3. Bioaccumulation factors for trace metals in fishes from Cochin backwaters

\begin{tabular}{|c|c|c|c|c|c|c|}
\hline \multirow[t]{2}{*}{ Trace metals } & \multicolumn{3}{|c|}{ E. suratensis } & \multicolumn{3}{|c|}{ A. arius } \\
\hline & Flesh & Liver & Gills & Flesh & Liver & Gills \\
\hline $\mathrm{Fe}$ & 1014.74 & 2868.57 & 2489.64 & 929.56 & 2515.83 & 2131.83 \\
\hline $\mathrm{Ni}$ & 478.43 & 827.13 & 930.41 & 431.14 & 630.60 & 605.24 \\
\hline $\mathrm{Zn}$ & 908.80 & 2709.12 & 2249.69 & 674.56 & 2108.74 & 1778.30 \\
\hline $\mathrm{Cu}$ & 174.66 & 795.04 & 380.56 & 145.52 & 702.91 & 277.51 \\
\hline $\mathrm{Pb}$ & 105.88 & 359.73 & 216.67 & 111.92 & 199.58 & 245.50 \\
\hline $\mathrm{Cd}$ & 105.64 & 193.87 & 207.69 & 92.75 & 178.59 & 181.30 \\
\hline $\mathrm{Cr}$ & 526.74 & 765.10 & 698.53 & 288.23 & 718.95 & 611.43 \\
\hline
\end{tabular}


Table 4. Metal selectivity index (\%) of fishes collected from Cochin backwaters

\begin{tabular}{lllllllll}
\hline Fishes & Organ & $\mathrm{Fe}$ & $\mathrm{Ni}$ & $\mathrm{Zn}$ & $\mathrm{Cu}$ & $\mathrm{Pb}$ & $\mathrm{Cd}$ & $\mathrm{Cr}$ \\
\hline E. suratensis & Flesh & 63.53 & 5.15 & 18.56 & 2.46 & 1.82 & 0.87 & 7.61 \\
& Liver & 65.58 & 3.25 & 20.21 & 4.09 & 2.26 & 0.59 & 4.03 \\
& Gills & 66.98 & 4.30 & 19.75 & 2.30 & 1.60 & 0.74 & 4.33 \\
\multirow{3}{*}{ A. arius } & Flesh & 68.05 & 5.42 & 16.11 & 2.40 & 2.25 & 0.90 & 4.87 \\
& Liver & 67.73 & 2.92 & 18.52 & 4.26 & 1.48 & 0.64 & 4.46 \\
& Gills & 68.53 & 3.34 & 18.65 & 2.01 & 2.17 & 0.77 & 4.53 \\
\hline
\end{tabular}

Table 5. Tissue selectivity index (\%) off fishes collected from the Cochin backwaters

\begin{tabular}{|c|c|c|c|c|c|c|c|c|}
\hline Fishes & Organ & $\mathrm{Fe}$ & $\mathrm{Ni}$ & $\mathrm{Zn}$ & $\mathrm{Cu}$ & $\mathrm{Pb}$ & $\mathrm{Cd}$ & $\mathrm{Cr}$ \\
\hline \multirow[t]{3}{*}{ E. suratensis } & Flesh & 15.92 & 21.40 & 15.49 & 12.94 & 15.52 & 20.83 & 26.46 \\
\hline & Liver & 45.01 & 36.99 & 46.17 & 58.88 & 52.73 & 38.22 & 38.44 \\
\hline & Gills & 39.07 & 41.61 & 38.34 & 28.18 & 31.76 & 40.95 & 35.10 \\
\hline \multirow[t]{3}{*}{ A. arius } & Flesh & 16.67 & 25.86 & 14.79 & 12.92 & 20.09 & 20.49 & 17.81 \\
\hline & Liver & 45.11 & 37.83 & 46.23 & 62.43 & 35.83 & 39.46 & 44.42 \\
\hline & Gills & 38.22 & 36.31 & 38.98 & 24.65 & 44.08 & 40.05 & 37.77 \\
\hline
\end{tabular}

The TSI reveal that the accumulation of trace metals in the flesh of fishes was lowest when compared to the gill and liver. This is maybe due to the different physiological roles of these organs in fish metabolism (Merciai et al 2014). When compared to muscle, the gill and liver in fishes serve for respiration and metabolism and are considered as target organs for trace metal contaminant accumulation (Nair et al 2006). This is associated to the fact that food and water are the main routes of contaminant assimilation as it is directly linked with the metabolism and respiration (Reddy et al 2007). Trace elements assimilated from food that contaminated with wastewater effluents are ingested in fish body and are transported through the blood and gets incorporated in various tissues at variable degrees (Kojadinovic et al 2007, George et al 2021). When compared to the liver and gill, the low concentration of metals in the muscle of fish species may be the low metabolic activity and/or low levels of metal-binding proteins in the muscle. Unlike other tissues, the liver accumulates high concentrations of metals, irrespectively of the uptake route and is considered as an indicator of water pollution by trace metals since their concentrations accumulated in this organ are often proportional to those present in the aquatic environment. Consequently, the high level of metals accumulation in the fish liver followed by gill and muscle highlights an environmental indication of water pollution due to the persistent exposure of trace metals loaded from the industrial effluent discharges, agricultural run-off and domestic sewage inputs (George et al 2012, Robin et al 2012). Hence metal concentrations in organs of fishes could be used as an index to estimate the level of pollution in aquatic ecosystems (Karadede-Akin and Unlu 2007).

\section{CONCLUSION}

The accumulation of trace metals in fish tissues varied among species. The omnivorous species, E. suratensis accumulated a higher concentration of trace metals in fish tissues than the carnivorous species, $A$. arius. The liver and gill of fishes showed higher concentrations of metals when compared to the flesh tissue due to higher metabolic activity of the liver and gill when compared to muscle. Bioaccumulation of trace metals in aquatic life, especially fishes have possible detrimental effects and direct toxic effect on human life and hence have environmental concern worldwide.

\section{REFERENCES}

Ahmed IT 2021. Estimate of $\mathrm{Cd}, \mathrm{Pb}$ and physico-chemical properties in soils of Kani-qrzhala dumpsite in Erbil, Kurdistan region of Iraq. Indian Journal of Ecology 48(1): 55-60.

Al-Kahtani MA 2009. Accumulation of trace metals in Tilapia fish (Oreochromis niloticus) from Al-Khadoud Spring, Al-hassa, Saud Arabia. American Journal of Applied Science 6(12): 2024-2029.

Al-Yousuf MH, El-Shahawi MS and Al-Ghais SM 2000. Trace metals in liver, skin and muscles of Lenthrinus lentjan fish species in relation to the body length and sex. Science of the Total Environment 256: 87-94.

Anu PR, Jayachandran PR, Sreekumar PK. and Bijoy Nandan S 2014. A review on trace metal pollution in Cochin backwaters, southwest coast of India. International Journal of Marine Science 4(10): 92-98.

Authman MMN 2008. Oreochromis niloticus as a biomonitor of trace metal pollution with emphasis on potential risk and relation to some biological aspects. Global Veterinaria 2(3): 104-109.

Ayotunde EO, Offem BO and Ada FB 2012. Heavy metal profile of water, sediment and fresh water cat fish, Chrysichthys nigrodigitatus (Siluriformes: Bagridae), of Cross River, Nigeria. Revista de Biología Tropical 60(3): 1289-1301.

Balachandran KK, Laluraj CM, Nair M, Joseph T, Sheeba P and Venugopal P 2005. Trace metal accumulation in a flow restricted, tropical estuary. Estuarine Coastal and Shelf Science 65: $361-370$ 
Bindu KR, Deepulal PM, Gireeshkumar TR and Chandramohanakumar N 2015. Evaluation of trace metal enrichment in Cochin estuary and its adjacent coast multivariate statistical approach. Environmental Monitoring and Assessment 187: 519 .

Culioli J, Fouquoire A, Calendini S, Mori C and Orsini A 2009. Trophic transfer of arsenic and antimony in a freshwater ecosystem $A$ field study. Aquatic Toxicology 94(4): 286-293.

Elamin OA, Elfadil AG and Elhassan MA 2021. Analysis of metal concentrations in water samples nearby Wadafiea dumsite of solid waste in Khartoum North, Sudan. Indian Journal of Ecology 48(3): 785-789.

Elzwayie A, Afan HA, Allawi MF and El-Shafie 2017. Trace metal monitoring, analysis and prediction in lakes and rivers state of the art. Environmental Science and Pollution Research 24(13): 12104-12117.

Farombi EO, Adelowo OA and Ajimoko YR 2007. Biomarkers of oxidative stress and heavy metal levels as indicators of environmental pollution in African cat fish (Clarias gariepinus) from Nigeria Ogun River. International Journal of Environmental Research Public Health 4(2): 158-165.

Geldiay R and Balik S 2000. Turkiye Tatlisu Baliklan (In Turkish). Izmir Ege Universitesi Fen Fakultesi Kitaplar Sersi 519.

George R, Biju A, Martin GD and Gerson VJ. 2021. Distribution and concentration of trace metals in tissues of pelagic and demersal fishes from the coastal waters of Cochin. Environmental Forensics, (in press) DOI 10.1080/15275922.2021.1907820

George R, Martin GD, Nair SM and Chandramohanakumar N 2012. Biomonitoring of Trace metal pollution using fishes from the Cochin Backwaters. Environmental Forensics 13(3): 272-283.

George R, Martin GD, Nair SM, Shaji PT and Sini J 2016. Geochemical assessment of trace metal pollution in sediments of the Cochin backwaters. Environmental Forensics 17(2): 156-171.

George R, Martin GD, Nair SM and Chandramohanakumar N 2013. Biomonitoring of trace metal pollution using the bivalve molluscs, Villorita cyprinoides, from the Cochin backwaters. Environmental Monitoring and Assessment 185: 1031710331.

Hannibal MC, Elvira AC, Eunice PV, Madeleine PP, Marites CG and Marilou BM 2006. Trace metal and microbial analysis of Janitor fish (Pterygoplichthys spp.) in Laguna de Bay, Philippines. Journal of Environmental Science and Management 9(2): 31-40.

Hazrat A, Ezzat K and Ikram I 2019. Environmental chemistry and ecotoxicology of hazardous trace metals environmental persistence, toxicity and bioaccumulation. Hindawi Journal of Chemistry https://doi.org/10.1155/2019/6730305

Jayasooryan KK 2015. Accumulation of trace metals in selected benthic organisms and fishes of Vembanad lake Ecosystem. Ph.D. Dissertation, Mahathma Gandhi University, Kottayam, India

Karadede-Akin H and Unlu E 2007. Trace metal concentration in water, sediment and fish and some benthic organisms from Tigris River, Turkey. Environmental Monitoring and Assessment 131(1-3): 323-337.

Karlsson S, Meili M, Bergström U, Eco S and Safety AB 2002. Bioaccumulation factors in aquatic ecosystems- a critical review. Svensk Kämbränslehantering $A B$, Swedish Nuclear Fuel and Waste Management Co. 67.

Kojadinovic J, Potier M, Le Corre M, Cosson RP and Bustamante P 2007. Bioaccumulation of trace elements in pelagic fish from the Western Indian Ocean. Environmental Pollution 146: 548-566.

Lallu KR 2017. Dynamics of trace metals, rare earth elements and nutrients in Cochin estuary, south west coast of India. Ph.D. Dissertation, Cochin University of Science and Technology, Kochi, India

Mahesh M, Deepa M, Ramasamy EV and Thomas AP 2012. Accumulation of mercury and other trace metals in edible fishes from Cochin backwaters, southwest India. Environmental Monitoring and Assessment 184: 4233-4245.

Martin GD, George R, Shaiju P, Muraleedharan KR, Nair M and Chandramohanakumar N 2012. Toxic metals enrichment in the superficial sediments of a eutrophic tropical estuary (Cochin backwaters, Southwest coast of India). The Scientific World Journal 1-17.

Merciai R, Guasch H, Kumar A, Sabater S and Berthou EG 2014. Trace metal concentration and fish size Variation among fish species in a Mediterranean river. Ecotoxicology and Environmental Safety 107: 154161.

Nair M, Jayalakshmy KV, Balachandran KK and Joseph T 2006. Bioaccumulation of toxic metals by fish in a semi-enclosed tropical ecosystem. Environmental Forensics 7: 197-206.

Nwani CD, Nwachi DA, Okogwu OI, Ude EF and Odoh GE 2010. Heavy metals in fish species from lotic freshwater ecosystem at Afikpo, Nigeria. Journal of Environmental Biology 31(5): 595-601.

Obasohan EE 2008. Bioaccumulation of chromium, copper, manganese, nickel and lead in fresh water cichlid, Hermichromis fasciatus from Ogba River in Benin City, Nigeria. African Journal of General Agriculture 4: 141-152.

Pantelica A, Ene A and Georgescu LI 2012. Instrumental neutron activation analysis of some fish species from Danube River in Romania. Microchemical Journal 103: 142-147.

Reddy M S, Mehta B, Dave P, Joshi M, Karthikeyan L, Sarma V, Basha S, Ramachandraiah G, Bhatt PN 2007. Bioaccumulation of heavy metals in some commercial fishes and crabs of the Gulf of Cambay, India. Current Science 92: 14891491.

Robin RS, Muduli PR, Vardhan KV, Ganguly D, Abhilash KR and Balasubramanian T 2012. Heavy metal contamination and risk assessment in the marine environment of Arabian Sea, along the Southwest Coast of India. American Journal of Chemistry 2: 191-208 .

Sankar TV, Zynudheen AA, Anandan R and Nair PGC 2006. Distribution of organochlorine pesticides and trace metal residues in fish and shellfish from Calicut region, Kerala India. Chemosphere 65(4): 583-590.

Shibu MP, Balchand AN and Nambisan NPK 1990. Trace metal speciation in a tropical estuary: Significance of environmental factors. Science of the Total Environment 97/98: 267-287.

Siraj M, Shaheen M, Sthander AA, Khan A, Chivers D P and Yousafzai A M 2014. A comparative study of bioaccumulation of trace metals in two fresh water species, Aorichthys seenghala and Ompok bimaculatous at River Kabul, Khyber Pakhtunkhwa, Pakistan. Journal of Biodiversity and Environmental Sciences 4: 40-54.

Tao Yu, Yuan Z, Xiaona Hu and Wei M 2012. Distribution and bioaccumulation of trace metals in aquatic organisms of different trophic levels and potential health risk assessment from Taihu Lake, china. Ecotoxicology and Environmental Safety 81: 55-64.

Tiphaine C, Strady E, Harmelin- Vivien M, Radakovitch O, BrachPapa C, Crochet S, Knoery J, Rozuel E, Thomas B, Tronczynski $\mathrm{J}$ and Chiffoleau J 2019. Patterns of trace meetal bioaccumulation and trophic transfer in phytoplanktonzooplankton- small pelagic fish marine food web. Marine Pollution Bulletin 146: 1013-1030.

Uluturhan E and Kucuksezgin F 2007. Heavy metal contaminants in Red Pandora (Pagellus erythrinus) tissues from the Eastern Agean Sea, Turkey. Water Research 41(6): 1185-1192.

Ural M, Arca S, Ornekci GN, Demirol F, Songül Yüce, Uysal K, Çiçek A, Esengül Köse and Ali M 2012. Metal accumulation in sediment, water and freshwater fish in a Dam Lake. Toxicological and Environmental Chemistry 94(1): 49-55.

Yousafzai AM, Siraj M, Ahmad H and Chivers DP 2012. Bioaccumulation of trace metals in common carp: Implications for human health. Pakistan Journal of Zoology 44(2): 489-494.

Received 12 October, 2021; Accepted 28 December, 2021 